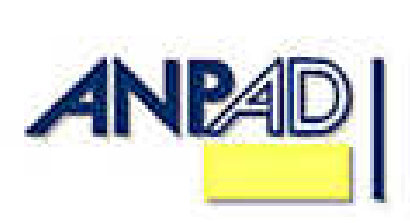

Disponível em

http://www.anpad.org.br/rac

RAC, Curitiba, v. 13, n. 4, art. 1,

pp. 525-544, Out./Dez. 2009

\title{
Olhando Além do "Primeiro Estruturalismo" para a Pesquisa em Marketing
}

\author{
Looking beyond the "First Structuralism" for Research in Marketing
}

Arcanjo Ferreira de Souza Neto * Mestre em Administração pela UFPE. Professor Assistente da UNIVASF, Petrolina/PE, Brasil.

Sérgio Carvalho Benício de Mello Ph.D. pela The City University, Cass Business School, Reino Unido. Professor Adjunto da UFPE, Recife/PE, Brasil.

\footnotetext{
* Endereço: Arcanjo Ferreira de Souza Neto

Universidade Federal do Vale do São Francisco, BR 4007, Km 08, Jardim São Paulo, Petrolina/PE, 56314-520. E-mail: arcanjoneto@ hotmail.com
}

Copyright (C 2009 RAC. Todos os direitos, inclusive de tradução, são reservados. É permitido citar parte de artigos sem autorização prévia desde que seja identificada a fonte. 


\section{RESUMO}

Atualmente, após décadas de um dominante encantamento com as teorias, os métodos e os resultados provenientes de pesquisas embasadas na tradição econômica ou psicológica de investigação, a disciplina do Marketing vem proclamando um espaço cada vez maior a utilização dos pressupostos teóricos e metodológicos oriundos da Antropologia, como forma de compreender de modo exato os matizes do universo simbólico atrelado às práticas de consumo de um determinado grupo ou cultura. O presente artigo procura contribuir para a aproximação das duas disciplinas em tela por meio do resgate e melhor entendimento dos fundamentos de uma via bastante cara à Antropologia, qual seja: o estruturalismo. Com a intenção de tornar mais cônscios de seus atos aqueles que, de algum modo, procuram estabelecer as estruturas daquilo que investigam, no presente artigo são discutidas algumas características gerais dos estruturalismos, as suas principais taxonomias, a significação da noção de estrutura, os princípios gerais que norteiam a realização de uma análise estrutural, o papel do pesquisador na busca das estruturas, bem como a relevância e a aplicabilidade potenciais das investigações estruturalistas na área de Marketing.

Palavras-chave: epistemologia estruturalista; princípios metodológicos do estruturalismo; aplicabilidade do estruturalismo ao Marketing.

\section{ABSTRACT}

Now, after decades of a dominant enchantment with theories, methods and research findings based in the economical or psychological traditions of research, the Marketing discipline is proclaiming an ever growing space of the use of theoretical and methodological assumptions originating from Anthropology as a form of understanding in a more acute way details of the symbolic universe harnessed to the practices of consumption of a certain group or culture. This paper helps bring together these two disciplines in question through the understanding of the foundations of a road beloved in Anthropology: structuralism. With the intention of raising awareness on the part of those who, by their actions, attempt to establish structures of what they research, this paper discusses some general characteristics of structuralisms, their main taxonomies, significance of the structure notion, general principles that guide a structural analysis, the researcher's role in the search for structures, as well as the relevance and potential applicabilities of structural investigations in Marketing.

Key words: structuralist epistemology; structural methodological principles; an applied structuralist approach to Marketing. 


\section{INTRODUÇÃO}

Há tempos que alguns autores da área de Marketing alertam para a importância do simbolismo subjacente às trocas que ocorrem no contexto de consumo (ver, por exemplo, Bagozzi, 1975; Levy, 1959). Após décadas de um dominante encantamento com as teorias, os métodos e os resultados provenientes de pesquisas embasadas na tradição econômica ou psicológica de investigação, juntamente com a assunção bastante difundida do positivismo lógico e sua inclinação à produção de conhecimento dito 'quantitativo', a disciplina do Marketing vem proclamando um espaço cada vez maior para a utilização dos pressupostos teóricos e metodológicos oriundos de outras disciplinas, como, por exemplo, da Antropologia, como forma de compreender os matizes do universo simbólico atrelado às práticas de consumo de um determinado grupo ou cultura (ver, por exemplo, Boas, Sette, \& Abreu, 2004; Jaime, 2001; Rocha et al., 1999). A própria Antropologia, aliás, ao estimular a constituição de um subcampo denominado 'Antropologia do consumo' (ver, por exemplo, Douglas \& Isherwood, 2004; Leitão, Lima, \& Machado, 2006; Miller, 2000), procurando com isso incluir o estudo do fenômeno do consumo em meio ao entendimento das culturas como sistemas simbólicos, vem pavimentando um caminho para a aproximação com o Marketing.

Em meio aos referidos esforços de aproximação, praticantes e acadêmicos da área de Marketing são estimulados principalmente a fazerem uso da Etnografia (procedimento metodológico tradicional na Antropologia) ou até mesmo a Etnografia (versão adaptada da primeira para o mundo virtual) em seus trabalhos e, com isso, contribuírem para a instituição do chamado 'Marketing Etnográfico' (ver, por exemplo, Barbosa, 2003; Neves \& Giglio, 2004; Rocha, Barros, \& Pereira, 2005). Sem querer discorrer sobre os limites, as vantagens ou desvantagens associadas ao emprego do método etnográfico no âmbito do Marketing, muito menos enveredar pela já desgastada discussão da primazia ou não dos ditos estudos qualitativos no acesso aos significados e simbolismos, o presente artigo procura contribuir para a aproximação das duas disciplinas em tela: o Marketing e a Antropologia. Pretende-se ainda, discutir os fundamentos do estruturalismo, que é pouco explorado na literatura de Marketing.

Embora os limites atuais do estruturalismo não sejam completamente nítidos - pois, dentre outras coisas, cada pesquisador, em razão do seu objeto de estudo e/ou de seu gênio pessoal, inventa ou defende novas modalidades de sua aplicação (cf. Kurzweil, 1980; Lepargneur, 1972), as raízes daquilo que se convencionou denominar pensamento estruturalista remontam explicitamente à Lingüística (em primeira instância), tendo como grande expoente Ferdinand de Saussure, e à Etnologia (em segunda instância), tendo como grande expoente Claude Lévi-Strauss (Benveniste, 1971; Gil, 1999). O pensamento estruturalista teve grande importância no desenvolvimento das ciências sociais no Século $\mathrm{XX}$; as idéias propaladas por tais autores fizeram com que alguns estudiosos dos fenômenos sociais desviassem a atenção da simples documentação de eventos históricos ou registro do comportamento humano e passassem a considerar as ações humanas como sistemas de significados, visando com isso alcançar a melhor compreensão possível dos mecanismos ocultos (i.e., inconscientes aos membros individuais dos grupos sociais estudados) que regem o funcionamento de cada um desses sistemas (cf. Walle, 2002).

A partir dos trabalhos dos referidos autores, a perspectiva estruturalista passa a ser discutida na Matemática (ver Barbut, 1968; Piaget, 1979), na Física (ver Piaget, 1979), na Biologia (ver Piaget, 1979; Wolff, 1971), na Psicologia (ver Dor, 1989; Lagache, 1971; Viet, 1973), na Sociologia (ver Gurvitch, 1971; Viet, 1973), na Economia (ver Perroux, 1971), na Ciência_Política (ver Godelier, 1968; Viet, 1973), no Direito (ver Carbonnier, 1971), e em muitos outros campos do conhecimento. Em alguns desses campos, o estruturalismo ocupou e ainda ocupa papel de destaque. Em outros, no entanto, as suas idéias foram incorporadas apenas parcialmente. No campo da gestão, conforme ThiryCherques (2006), o estruturalismo tem pouca influência direta e nem sempre os seus pressupostos são compreendidos adequadamente pelos pesquisadores. Tal situação pode ser considerada preocupante.

Como algumas das razões para a incompreensão do estruturalismo nas pesquisas em Administração, o supracitado autor reconhece o desconhecimento dos seus preceitos elementares e a carência de 
exposições sobre o emprego prático do método ajustado à área. Levando essa crítica mais além, ou melhor, trazendo-a para o escopo do Marketing, pode-se dizer que embora alguns trabalhos empíricos já tenham sido desenvolvidos na área sob influência explícita da perspectiva antropológica (ver, por exemplo, Levy, 1981; Souza \& Mello, 2006; Stern, 1995; Walle, 2002) e outros tenham sido realizados, utilizando nomenclaturas que remetem a uma concepção estrutural (como, por exemplo, aqueles que empregam as tão difundidas equações estruturais), poucos são os esforços direcionados pelos estudiosos e pesquisadores de marketing à apresentação sistematizada das principais idéias estruturalistas (Walle, 2002, é uma honrosa, embora superficial, exceção) e até o momento, pelo que se pôde observar, a discussão aprofundada sobre os conceitos fundamentais e princípios gerais das análises estruturais, sua relevância e aplicabilidades potenciais na pesquisa em marketing não foram desenvolvidas.

O presente trabalho procura, portanto, auxiliar no preenchimento desta lacuna e, com isso, tornar mais cônscios de seus atos aqueles que, de algum modo, procuram estabelecer as estruturas daquilo que investigam. Cabe ressaltar que não será dado aqui enfoque exclusivo ao que Thiry-Cherques (2006) chama de "primeiro estruturalismo" (i.e., os trabalhos desenvolvidos por Claude Lévi-Strauss); mas, visando ampliar as contribuições do referido autor, buscar-se-á olhar além e entender aquilo que é fundamental a praticamente todas as formas de estruturalismo. Inicialmente, são discutidas algumas características gerais dos estruturalismos e apresentadas rapidamente as suas principais taxonomias. Em seguida, é discutida a significação da noção de estrutura. Na seqüência, os princípios gerais que norteiam a realização de uma análise estrutural são apresentados, e o papel do pesquisador na busca pelas estruturas é discutido. Por fim, a relevância e a potencialidade das investigações estruturalistas na área de Marketing são discutidas.

\section{CARACTERÍSTICAS GERAIS DOS ESTRUTURALISMOS}

Ainda que não se deva falar em estruturalismo, no singular, como se ele fosse uma única escola ou movimento (cf. Barthes, 1967), algumas características presentes (em maior ou menor grau) em todos os estruturalismos podem ser identificadas e associadas a certa "maneira de pensar" (Pouillon, 1968), que se imagina ser comum aos investigadores que buscam compreender as estruturas dos fenômenos que estudam. Obviamente, não se pretende exaurir a análise de todas elas, apenas comentar brevemente as que se acredita serem as principais.

Para Demo (1995), uma das marcas do pensamento estruturalista é a acentuação de que o conhecimento da realidade se realiza plenamente apenas quando atinge nela constantes supratemporais $^{(1)}$ e supra-espaciais ${ }^{(2)}$. Com isso, busca-se descobrir invariantes que expliquem a variedade dos fenômenos, já que se pressupõe que a variação só pode ser explicada, quando se descobre como ela invariavelmente varia. Contudo o pensamento estruturalista não parece estar interessado em descobrir a razão pela qual uma determinada variação, entre todas as possíveis a partir do mesmo sistema, foi a solução privilegiada em um dado momento ou local. O que ele pretende é esclarecer o que não pode advir, e situar a solução que a História promove no quadro prévio das possibilidades teóricas (cf. Escobar, 1967; Lepargneur, 1972). Por sua vez, Viet (1973) ressalta que para o pensamento estruturalista, o conhecimento dos fatos da vida humana e social, para ser conhecimento da realidade, deve tomar o caminho de uma integração desses fatos numa totalidade. Dessa forma, enquanto o empirismo concebe a realidade como singular e revelada graças à experiência sensível, passando o objeto nessa perspectiva a ser o que ele é, ou seja, o fato, o pensamento estruturalista assume que o estudo do fato isolado é insignificante, posto que o fato, enquanto tal, não possui significado (cf. Bonomi, 2001; Châtelet, 1968; Pouillon, 1968). Assim, o pensamento estruturalista procura sempre, por trás das aparências, ou seja, além da [des]organização aparente do objeto, estruturas inteligíveis que expliquem certo funcionamento (Barthes, 1967) e, desse modo, pode-se dizer que não existe estruturalismo sem a pretensão de superar uma simples descrição da materialidade do fenômeno e, com isso, conseguir desvelar uma racionalidade até então oculta, 
onde o olhar superficial, na maioria das vezes, não percebe senão desordem e não acha outra explicação senão o acaso (cf. Coelho, 1968; Escobar, 1967; Lepargneur, 1972).

Outro aspecto que, segundo Piaget (1979), é comum aos estruturalismos diz respeito ao ideal de inteligibilidade intrínseca, fundado sobre o postulado que uma estrutura, para ser apreendida, não requer o recurso a elementos estranhos à sua natureza. Nesse sentido, Châtelet (1968) também ressalta que a probidade dos estruturalistas está em continuarem a investigar, no domínio que escolheram, e a procurar o meio de assegurar, em relação aos objetos empíricos e às produções teóricas que interpelam, a máxima inteligibilidade. Piaget (1979) constata ainda que, em todos os estruturalismos, o estudioso recorre, cedo ou tarde, a um determinado modo de formalização. Salientando este aspecto, Viet (1973) declara que para ter reais implicações metodológicas, é preciso que a estrutura seja especificada, que ela se torne, por exemplo, forma ou modelo. Entretanto, como a formalização é obra particular de cada estudioso, existem diferentes graus possíveis de formalização a depender de suas decisões (cf. Piaget, 1979). Assim, é possível que dois ou mais pesquisadores que venham a trabalhar sobre o mesmo conjunto de dados (ou mesmo objeto) cheguem a formalizações diferentes. Por fim, vale destacar que, diante dos seus mais diversos usos e variantes, Barthes (1967) prefere referir-se ao estruturalismo como sendo uma atividade, ou seja, uma sucessão regulada de certo número de operações mentais. Para ele, então, o fim de toda atividade estruturalista é "reconstituir um 'objeto', de maneira a manifestar nesta reconstituição as regras do funcionamento (as 'funções') deste objeto" (Barthes, 1967, p. 58).

Em face do rol de características apresentadas na presente seção (principalmente o desapego à primazia dos dados empíricos, os quais passam a servir sobretudo para estimular a reflexão e, posteriormente, exemplificar modelos ou teorias), pode-se defender a idéia de que o pensamento estruturalista representa uma alternativa às diversas formas de positivismo (cf. Richardson, 1999). A Tabela 1 abaixo, apesar de ser introdutório e limitado em escopo, possibilita ao leitor apreciar diferenças e quiçá corroborar o argumento apresentado.

\section{Tabela 1: Positivismo como uma Interpretação das Ciências e uma Classificação do Conhecimento}

\begin{tabular}{|l|l|}
\hline $\begin{array}{c}\text { O Positivismo e algumas } \\
\text { Diferentes Denominações }\end{array}$ & \multicolumn{1}{c|}{$\begin{array}{c}\text { Significado de Positivismo } \\
\text { para Diferentes Correntes Epistemológicas }\end{array}$} \\
\hline Positivismo Moderno & $\begin{array}{l}\text { O significado de uma proposição ou hipótese está relacionado } \\
\text { diretamente aos dados empíricos que resultam de sua observação. } \\
\text { Estabelece a lógica indutiva, os testes empíricos ou observaçôes } \\
\text { sucessivas e oferece os primeiros insights sobre a importância da } \\
\text { linguagem. O esquema lógico básico do princípio da verificação do } \\
\text { Positivismo moderno é o seguinte: Indutivismo (observação via } \\
\text { experiência dos sentidos e da razão humana); Causas (teorias - } \\
\text { proposições/hipóteses) } \rightarrow \text { Efeitos (fatos - o enunciado) } \rightarrow \text { Verificação } \\
\text { (legitimação do conhecimento); As Bases Metafísicas (hermenêutica } \\
\text { dos resultados) } \rightarrow \text { Questão do Método (objetividade). }\end{array}$ \\
\hline
\end{tabular}




\section{Tabela 1 (continuação): Positivismo como uma Interpretação das Ciências e uma Classificação do Conhecimento}

\begin{tabular}{|c|c|}
\hline $\begin{array}{l}\text { O Positivismo e algumas } \\
\text { Diferentes Denominações }\end{array}$ & $\begin{array}{c}\text { Significado de Positivismo } \\
\text { para Diferentes Correntes Epistemológicas }\end{array}$ \\
\hline Neo-Positivismo & $\begin{array}{l}\text { Um novo significado é produzido a partir da valorização da idéia de } \\
\text { verdade não mais como representação projetiva de fatos, mas como } \\
\text { coerência entre proposições/hipóteses e consequiência da interpretação } \\
\text { dos significados subjetivamente intencionados. O esquema lógico } \\
\text { básico do princípio da verificação do Neo-Positivismo é o seguinte: } \\
\text { Dedutivismo (significados socialmente construídos); Causas (teorias - } \\
\text { proposições/hipóteses com significado social) } \rightarrow \text { Efeitos (não existem } \\
\text { fatos em si, mas apenas interpretações) } \rightarrow \text { Verificação (legitimação do } \\
\text { conhecimento); As Bases Metafísicas e a Questão do Método (o saber } \\
\text { é extrametódico baseado na interpretação onde a validade de uma } \\
\text { teoria se comprova na competência lingüística dos partidários da } \\
\text { comunidade científica em questão). }\end{array}$ \\
\hline Realismo Crítico & $\begin{array}{l}\text { A realidade existe objetivamente independente da percepção e da } \\
\text { observação que temos dela. Esta corrente de pensamento parte do } \\
\text { pressuposto de que o conhecimento de um objeto se faz através dos } \\
\text { sentidos. O que estes captam é a própria coisa. A sensação é sempre } \\
\text { sensação do objeto. O conhecimento, na verdade é um processo } \\
\text { limitado, sempre parcial, que não pode prescindir do contexto } \\
\text { histórico-social no qual o mesmo conhecimento se forma. O esquema } \\
\text { lógico básico do princípio da verificação do Realismo crítico segue os } \\
\text { princípios do Neo-Positivismo apresentados acima introduzindo as } \\
\text { proposições protocolares. Nele o esquema para elaboração das } \\
\text { proposições/hipóteses é o seguinte: Proposições de observações (via } \\
\text { experiência dos sentidos e da razão humana) } \rightarrow \text { Proposições de } \\
\text { experiências (vivenciais elementares/significação social) } \rightarrow \\
\text { Proposições protocolares (observações de um indivíduo em um certo } \\
\text { contexto). }\end{array}$ \\
\hline
\end{tabular}

Fonte: elaborada pelos autores.

Tendo analisado, brevemente, alguns aspectos básicos dos estruturalismos e de suas possibilidades epistemológicas, nas seções seguintes serão ampliadas as discussões na direção de princípios gerais, conceitos fundamentais, relevâncias e aplicabilidades potenciais na pesquisa em marketing. No entanto, antes de o pesquisador poder decidir efetivamente por sua adoção ou não no âmbito do Marketing, é interessante que ele conheça as suas principais vertentes.

\section{Principais Taxonomias dos Estruturalismos no Escopo das CiênCias Humanas E SOCIAIS}

Uma forma genérica de classificar as vertentes do estruturalismo (ver Tabela 2) é associá-las à disciplina na qual cada uma se situa. No entanto essa forma de classificação não é precisa, pois o próprio desenvolvimento dos estudos em cada uma dessas disciplinas tende a dividir o seu estruturalismo em tão diversas interpretações que, na maioria das vezes, sob a etiqueta comum de estruturalismo em dado campo, encontram-se escolas de inspiração e tendências bastante divergentes. Ainda assim, deve-se reconhecer que um ponto de partida razoável (ou mínimo, talvez) é considerar que existem os estruturalismos das ciências humanas e sociais e os que nitidamente se situam fora delas (os quais evidentemente não serão aqui abordados). 
Tabela 2: Classificação das Principais Vertentes do Estruturalismo

\begin{tabular}{|c|c|}
\hline $\begin{array}{l}\text { O 'estruturalismo' e } \\
\text { algumas Diferentes } \\
\text { Denominações }\end{array}$ & $\begin{array}{c}\text { Significado de 'estruturalismo' } \\
\text { para Diferentes Correntes Epistemológicas }\end{array}$ \\
\hline Global & $\begin{array}{l}\text { Que se apóia no sistema das relações observáveis, considerado auto- } \\
\text { suficiente. }\end{array}$ \\
\hline Metódico & $\begin{array}{l}\text { Procura a explicação desse sistema numa estrutura subjacente que permite a } \\
\text { sua interpretação dedutiva. }\end{array}$ \\
\hline dos Modelos & $\begin{array}{l}\text { Como um modelo dado reage às modificações em algum de seus elementos } \\
\text { ou compara os modelos entre si. }\end{array}$ \\
\hline Genético & $\begin{array}{l}\text { O sentido é adquirido na constituição de uma totalidade dinâmica e o ser da } \\
\text { estrutura é sua própria estruturação. }\end{array}$ \\
\hline Fenomenológico & $\begin{array}{l}\text { Orienta-se para apreensão das invariantes presentes nas experiências } \\
\text { concretas dos homens tais como elas se apresentam no plano do vivido. }\end{array}$ \\
\hline Dialético & $\begin{array}{l}\text { A predominância da totalidade sobre os momentos particulares, pois as } \\
\text { partes encontrariam no conjunto seu conceito e sua verdade na perspectiva } \\
\text { de uma nova síntese. }\end{array}$ \\
\hline Concreto & $\begin{array}{l}\text { Nessa visão, as relações sociais existentes podem ser unificadas em uma } \\
\text { manifestação estrutural da realidade concreta a ser compreendida. }\end{array}$ \\
\hline Abstrato & $\begin{array}{l}\text { A estrutura não está relacionada diretamente com a realidade empírica, mas } \\
\text { com os modelos construídos em sua função. }\end{array}$ \\
\hline Mental & $\begin{array}{l}\text { Enfocam o entendimento dos processos internos (pretensamente universais) } \\
\text { da mente humana. }\end{array}$ \\
\hline Social & $\begin{array}{l}\text { Enfocam o entendimento das estruturas socioculturais, bem como as formas } \\
\text { pelas quais tais estruturas auxiliam na satisfação das necessidades tanto da } \\
\text { sociedade quanto dos indivíduos. }\end{array}$ \\
\hline
\end{tabular}

Fonte: elaborada pelos autores.

Nas ciências humanas e sociais, Piaget (1979) classifica os estruturalismos em globais ou metódicos Concebendo uma estrutura como sistema de transformações que comporta suas leis enquanto totalidade (por oposição às propriedades isoladas dos elementos), o autor afirma que todas as pesquisas que dizem respeito à sociedade conduzem a estruturalismos, já que os conjuntos ou subconjuntos sociais se impõem de imediato enquanto totalidades. No entanto, ele alega que, ao contrário desse estruturalismo global (que se apóia no sistema das relações observáveis, considerado auto-suficiente), o estruturalismo metódico procura a explicação desse sistema numa estrutura subjacente que permite a sua interpretação dedutiva. Nesse caso, a estrutura não faz parte dos fatos constatáveis e permanece em grande parte (talvez até completamente) inconsciente aos membros individuais do grupo considerado.

Ao procurar também identificar as tendências estruturalistas, Viet (1973) encontra três tipos gerais: fenomenológico, genético e dos modelos. Já Motta e Vasconcelos (2002) sugerem quatro tipos principais: fenomenológico, dialético, concreto e abstrato. Por fim, Walle (2002) identifica duas macro-orientações: mental e social ${ }^{(3)}$. Fora pequenas redundâncias, percebe-se que, ao invés de se excluírem, tais classificações se complementam. Assim, elas serão brevemente apresentadas, destacando-se aquela proposta por Walle (2002).

O estruturalismo fenomenológico adota a atitude de voltar ao mundo antes que ele seja submetido às rígidas determinações da ciência (Motta \& Vasconcelos, 2002). Ao fazer isso, esta corrente recusa a atitude natural que coloca a existência do mundo em si como objeto (i.e., como algo previamente dado) e orienta-se para apreensão das invariantes presentes nas experiências concretas dos homens, tais como elas se apresentam no plano do vivido, mas tendo aí também a possibilidade de ultrapassar o mero ponto de vista do sujeito, notadamente quando a reflexão se exerce sobre a essência desse vivido 
(Viet, 1973). Desse modo, para Bonomi (2001), a Fenomenologia está interessada na compreensão da estrutura da relação intencional do sujeito com o objeto e todo dado (mesmo o mais ínfimo dado sensorial) aparece para ela num contexto relacional, participando de uma estrutura. Assim, a estrutura é aqui encarada como construção informadora do objeto (ver Bastide, 1971). Atualmente, é notório o espaço que essa vertente vem conquistando na área de marketing (acerca disso ver, por exemplo, Carvalho \& Vergara, 2002; Cerchiaro, Sauerbronn, \& Ayrosa, 2004).

Ao contrário da intuição dos fenomenólogos, que constitui uma visão intemporal das essências, a apreensão do sentido se reveste, para o estruturalismo genético, de uma dimensão temporal (cf. Viet, 1973). Aqui, o sentido é adquirido na constituição de uma totalidade dinâmica e o ser da estrutura é sua própria estruturação (Piaget, 1979). Assim, o equilíbrio alcançado é provisório e a unificação dos fatos visada pela investigação nunca pode ser dada como concluída, pois toda estrutura tem uma vida e uma história. Contudo, devido à propriedade de auto-regulação, as transformações inerentes à estrutura engendram elementos que sempre lhe pertencem e que conservam suas leis. Já no tocante ao estruturalismo dialético, Motta e Vasconcelos (2002) observam que a análise que descobre as partes força a preparar seu surgimento ao longo do desenvolvimento do todo, como um episódio de sua história. Por outro lado, a diferenciação permite pensar a integração e voltar à totalidade, sem fazer uma simples soma, pois, desde que as partes tenham adquirido autonomia, é pelas relações entre elas que o todo pode ser restaurado. Por sua vez, Viet (1973) aponta aqui a predominância, pelo menos metodológica, da totalidade sobre os momentos particulares, pois as partes encontrariam no conjunto seu conceito e sua verdade. Assim, o que conta é a passagem ao todo, e se ele deve ser questionado, ele o é na perspectiva de uma nova síntese. Daí um dinamismo da estrutura, pois tal concepção também compreende a realidade enquanto devir.

O estruturalismo concreto considera a estrutura a própria definição do objeto (ver Bastide, 1971). Nessa visão, as relações sociais existentes, em dado momento, podem ser unificadas em uma rede dotada de continuidade na qual se podem encontrar posições e funções sociais e que se constitui em uma manifestação estrutural da realidade concreta a ser compreendida. Para Viet (1973), em tal concepção é necessário, primeiramente, apreender no plano empírico as relações sociais e coordenálas num conjunto ou estrutura, para em seguida tentar explicá-las. Já no estruturalismo abstrato, a estrutura não está relacionada diretamente com a realidade empírica, mas com os modelos construídos em sua função. Assim, Lévi-Strauss (1996) entende que compreender é reduzir a realidade a um modelo, considerando duas espécies de ordens, as vividas, funções da realidade objetiva, e as concebidas, interpretações das primeiras. A estrutura aqui é, afirma ele (1971b, p. 166), "uma potência do objeto, mediante a qual posso ultrapassá-lo, construir uma espécie de 'super-objeto' que é ... um sistema de relações" e que pode ser definido pela lei de combinação de seus elementos (cf. Viet, 1973). Em vista disso, a experimentação sobre os modelos difere da experimentação pelos modelos, pois a última permanece no nível empírico, enquanto a primeira procura saber como um modelo dado reage às modificações em algum de seus elementos ou comparar os modelos entre si. Neste caso, deve-se partir de um fenômeno concreto e, pela abstração reflexiva, criar um modelo representativo do objeto de estudo para, finalmente, retornar ao concreto como realidade estruturada. De acordo com Lévi-Strauss (1996), os modelos, para serem estruturais, devem: a) oferecer caráter de sistema, isto é, consistir em elementos tais que uma modificação em um deles modifique todos os outros; b) pertencer a um grupo de transformações, cada uma das quais correspondendo a um modelo da mesma família; c) permitir a previsão do modo de reação do modelo em caso de modificação de algum de seus elementos. Para o referido autor, os modelos podem ainda ser conscientes ou inconscientes, segundo o nível em que funcionam, bem como mecânicos ou estatísticos, de acordo com a congruência da escala de seus elementos com a escala dos fenômenos observados.

Segundo Walle (2002), os estruturalismos mentais enfocam o entendimento dos processos internos (pretensamente universais) da mente humana. Os fenômenos que os indivíduos percebem teriam as características que lhes foram atribuídas por causa do modo como os sentidos operam e do modo como o cérebro e a mente humana estão organizados para ordenar e interpretar os estímulos que recebem. Na à área de Marketing, Walle (2002) cita como exemplos de aplicações diretas dos pressupostos dessa corrente um trabalho de Levy (1981) - o qual demonstrou como o estruturalismo pode ser utilizado 
na busca de melhor compreensão do modo como os consumidores concebem os produtos e como escolhem consumi-los; um trabalho de Dichter (1964) - o qual demonstrou que a teoria freudiana pode explicar o fato de os consumidores serem motivados por atributos dos produtos que estão além de suas características funcionais; e um trabalho dele próprio, no qual utiliza a teoria jungiana, para interpretar um conjunto de campanhas promocionais que lidam com heróis do esporte e, a partir disso, demonstrar que atletas que atuam em determinadas carreiras possuem um potencial maior para exercer influência sobre as respostas dos consumidores.

Os estruturalismos sociais, por sua vez, enfocam o entendimento das estruturas das sociedades e/ou culturas (i.e., buscam compreender como elas se encontram estruturadas), bem como as formas pelas quais tais estruturas auxiliam na satisfação das necessidades, tanto da sociedade quanto dos indivíduos. Na área de Marketing, Walle (2002) menciona como exemplo dessa corrente o estudo realizado por Holbrook e Grayson (1986) - o qual demonstrou que tanto a pesquisa com consumidores pode ser utilizada para a compreensão da cultura popular quanto as respostas dos consumidores podem ser exploradas por meio da análise dessa cultura. No entanto, seguindo as características presentes nas indicações de Walle (2002), também poderiam ser citados como exemplos, na área de Marketing, trabalhos de autores como Barbara Stern, Elizabeth Hirschman, Stephen Grove e Raymond Fisk.

Walle (2002) observa ainda que, embora os estruturalistas mentais tendam a encarar as culturas como manifestações particulares da natureza universal humana, eles admitem o impacto das estruturas culturais sobre o pensamento humano. Eles encaram o ambiente social, pois, como uma extensão das estruturas mentais e tentam compreender como elas influenciam a vida social e o processo decisório. Assim, tais estruturalismos são flexíveis para lidar com as respostas de culturas específicas, não apenas com padrões universais. Os estruturalismos sociais, por outro lado, tipicamente não rejeitam a premissa de que a mente humana possua alguma estrutura, pois tal fato para eles se torna secundário, ao assumirem que qualquer padrão universal do pensamento humano passa por um filtro cultural, sendo transformado de acordo com ele. Assim, para eles, os padrões da mente humana são apenas alguns dos fatores pré-existentes que impactam as culturas e conduzem ou facilitam a vida em sociedade.

\section{A Polissêmica Noção de ESTrutura: SEUS ConteXtos e AXIomáticas}

Segundo Bastide (1971, p. 2), a palavra 'estrutura' deriva do verbo struere (construir) e, a partir da terceira década do Século XX, o seu emprego passa a se expandir acentuadamente em várias direções. Em vista disso, "entre os conceitos básicos das ciências humanas, o de estrutura é, sem dúvida, um dos mais obscuros" (Boudon, 1974, p. 4). Visando superar tal obscurecimento, vários colóquios e seminários já foram realizados. Entretanto nenhum conseguiu conferir ao conceito um sentido unívoco, talvez porque ele seja "epistemológico ao máximo" (cf. Roumeguère, 1971; Viet, 1973) e possua tantas conotações quantos são os autores que o empregam (cf. Lefebvre, 1967; Lévi-Strauss, 1971b). Sobre isso, Pagès (1971) afirma que, justamente por ser tão freqüente, o termo 'estrutura' pode ser considerado uma coleção de homônimos, entre os quais a maior parte admite também sinônimos. Em face a tais características, a noção de estrutura se torna, sem dúvida, polissêmica.

A admissão de tal polissemia conduz a algumas preocupações. Uma delas, esboçada por Bastide (1971), liga-se ao fato de que, segundo ele, nenhuma ciência realizou progressos substanciais sem ter um vocabulário técnico perfeito, que possibilitasse o trabalho em comum. Embora se possa questionar quanto tal perfeição seja necessária, não se pode negar que muita confusão já tenha sido (e continue a ser) gerada no uso da palavra estrutura. Outra preocupação, esboçada por Viet (1973), é a de que a noção de estrutura não seja confundida com a de imagem concreta, mas simplificada, dos fenômenos, nem com a da essência abstrata da realidade. Coelho (1968), por sua vez, observa que muito daquilo que se passou a atribuir à noção de estrutura já existia sob outras designações aproximadas e sustenta que é necessário diferenciar esses diversos conceitos para saber o que realmente há de novo na noção de estrutura. Por fim, Boudon (1974) entende que a dificuldade não é estabelecer uma definição 
consensual (pois embora cada autor possa dar a sua definição, a noção normalmente evoca certas associações e oposições, tais como: estrutura-sistema de relações, estrutura-essência, estrutura/características aparentes, estrutura/agregado, etc.), mas saber por que e quando se deve preferir usar um termo que é mais obscuro do que os seus sinônimos.

Desse modo, recusando (como Lévi-Strauss, 1996) uma definição indutiva do termo estrutura, Boudon (1974) ${ }^{(4)}$ afirma que antes de analisar o conteúdo da noção - que segundo ele não permite distingui-la de suas associações sinonímicas - deve-se analisar o papel desta noção nos contextos em que ela aparece (para compreender sua significação), tendo em vista que grande parte dos equívocos a ela ligados é ocasionada justamente pela negligência da existência desses contextos, quais sejam: o das definições intencionais e o das definições efetivas.

No contexto das definições intencionais, Boudon (1974) mostra que o termo estrutura é usado tanto para realçar o caráter sistêmico de um objeto (i.e., suas interdependências), quanto para sublinhar que um método tem por efeito descrever um objeto como um sistema. Nesse caso, como o objeto que se procura descrever (ex: conjunto de indivíduos reunidos em uma mesma tarefa) evoca as mesmas associações que a própria palavra estrutura, a significação da noção se reduziria à de suas associações sinonímicas (estrutura-totalidade, estrutura-sistema de relações etc.), as quais poderiam então substituí-la sem problema. Não se verificaria nesse contexto, portanto, uma necessidade, mas sim uma comodidade no emprego da palavra estrutura, a qual em geral seria usada principalmente para opor certas categorias de objetos ou certas maneiras de apreender um objeto a outras que não evocam as associações sinonímicas do termo estrutura. $\mathrm{O}$ emprego aqui de tal palavra serviria para descrever uma intenção de construir ou de apresentar uma teoria, analisando a interdependência dos elementos de um objeto-sistema, embora, muitas vezes, a intenção não origine e não possa originar uma realização efetiva, seja porque o objeto assim não o permita, seja porque, em determinado momento, não se disponha do aparato mental necessário para tanto.

No contexto das definições efetivas, Boudon (1974) argumenta que a noção de estrutura se insere em uma teoria destinada a explicar (e não simplesmente demonstrar, como ocorre no contexto anterior) o caráter sistemático de um objeto, procurando com isso entender por que ele se encontra em ordem e não em desordem, bem como compreender o porquê da presença de uma ordem particular ${ }^{(5)}$. A estrutura é aqui a descrição que resulta de um conjunto de proposições teóricas ou axiomas e, por isso, a sua significação não pode ser compreendida sem referência à construção lógica ou à teoria de que é solidária. Admitindo-se que a estrutura de um sistema é sempre o resultado de uma teoria hipotético-dedutiva, aplicada a este sistema, constata-se que certas restrições impostas pela natureza do material examinado podem fazer com que esta teoria assuma formas lógicas diversas. Não há necessidade, contudo, de que a noção de estrutura esteja relacionada, neste ou no outro contexto, a um modelo matemático ${ }^{(6)}$. Aliás, como Boudon (1974) demonstra, a palavra estrutura freqüentemente aparece sem que a teoria hipotético-dedutiva associada à descrição de um material particular possa ser considerada exatamente um modelo. Assim, as definições da noção de estrutura, sejam elas intencionais ou efetivas, podem ou não estar associadas a critérios rigorosos (i.e., definidos sem ambigüidade), ou melhor, a critérios com os mais variados níveis de rigor.

Em face do exposto, Boudon (1974) afirma que as fontes de homonímia no contexto das definições efetivas são basicamente duas. A primeira diz respeito ao fato de as teorias associadas à noção de estrutura poderem ser de tipos lógicos diferentes. Desse modo, em uma primeira situação, as teorias são sistemas hipotético-dedutivos verificáveis, isto é, possuem a forma lógica de um conjunto de proposições ou axiomas a partir dos quais é possível obter, por dedução, novas proposições ou conseqüências. O sistema de proposições assim formado é verificável, à medida que algumas de suas conseqüências (talvez até todas) podem ser comparadas às propriedades do objeto analisado. Em uma segunda situação, a teoria continua a ser um sistema hipotético-dedutivo, mas a sua verificação não pode ser obtida pela aplicação de um critério simples e completamente desprovido de ambigüidade. Entretanto isto não quer dizer que ela deva ser chamada impossível. A teoria pode ser compatível com grande número de fatos, sem que esta compatibilidade constitua um critério de verificação tão estrito quanto aquele que se faz presente na situação precedente. Na situação em foco, não se pode afirmar que a ausência de coincidência entre a ordem teórica e as ordens empíricas constitua uma refutação 
não-equívoca e definitiva da teoria ${ }^{(7)}$. Sendo assim, Boudon (1974) argumenta que a teoria se encontra associada a procedimentos de verificação indiretos. Em uma terceira situação, a teoria ainda é um sistema hipotético-dedutivo, mas já não se podem definir a seu propósito critérios de verificação, sejam diretos ou indiretos. Embora não seja propriamente verificável, tal teoria (e.g., estrutura da personalidade) pode, por mecanismos complexos, envolver um grau de convicção variável e ser considerada mais ou menos verossímil.

A segunda fonte de homonímia no contexto em tela relaciona-se ao fato de os objetos (sistemas) aos quais se aplicam as análises estruturais diferirem em sua natureza, ou melhor, nas dificuldades que opõem à observação. Assim, enquanto alguns sistemas (ex: regras do casamento em uma sociedade, fenômenos de acentuação de uma língua) são constituídos por um conjunto de fatos, de características ou de componentes facilmente observáveis e cujo número é definido (finito), outros, no entanto, (e.g., valores de um grupo de consumidores) são constituídos por um conjunto de componentes nem sempre identificáveis e cujo número é indefinido. Existe ainda um caso intermediário, em que um sistema indefinido é, por meio da escolha arbitrária dos elementos retidos para a análise, transformado em um sistema artificialmente definido. Em tal caso (e.g., análise da relação entre intenções de compra e atitudes a respeito de uma marca para se chegar a uma compreensão do comportamento consumidor), o objeto proposto à análise é artificial, porque não há necessidade de serem consideradas apenas as características escolhidas e a quantidade de observações arbitrada, já que outras características podem ser imaginadas como explicativas do fenômeno sob estudo e o número (ou período) de observações pode, pelo menos em tese, ser sempre aumentado.

Tomadas em conjunto e analisadas de forma dicotômica, as duas fontes de homonímia no contexto das definições efetivas produzem, de acordo com Boudon (1974, p. 71), quatro tipos de meios fundamentais da noção de estrutura, conforme o quadro abaixo reproduzido:

Tabela 3: Os Quatro Tipos de Meios Fundamentais da Noção de Estruturas no Contexto das Definições Efetivas

\begin{tabular}{|l|c|c|}
\hline \multicolumn{1}{|c|}{ Teorias } & Objeto-sistema definido & Objeto-sistema indefinido \\
\hline Teoria verificável & Tipo 1 & Tipo 2 \\
\hline $\begin{array}{l}\text { Teoria indiretamente verificável ou } \\
\text { inverificável }\end{array}$ & Tipo 3 & Tipo 4 \\
\hline
\end{tabular}

Para o referido autor, a noção de estrutura aparece sem ambigüidade no interior de cada um destes tipos (onde os exemplos invocam apenas sinonímia), embora invoque uma sensação de homonímia quando se passa de um tipo a outro. Nas estruturas presentes no meio do tipo 1 ou 2, o pesquisador parte de um conjunto de dados, considerados interdependentes, emite hipóteses explicativas e verifica se elas permitem deduzir as características aparentes do sistema. Contudo, para se aplicar uma teoria verificável no meio 2, deve-se inicialmente transformar o sistema naturalmente indefinido em um sistema artificialmente definido. Apesar de ainda serem resultado de teorias hipotético-dedutivas, as estruturas presentes no meio do tipo 3 ou 4 são concebidas como estruturas sem axiomática ${ }^{(8)}$ aparente. Assim, no caso das estruturas do meio 3, os procedimentos de verificação da análise estrutural são muito menos automáticos que nos casos 1 ou 2 . No entanto, em seu princípio, consistem sempre em mostrar que a estrutura obtida constitui uma teoria explicativa dos fatos. Verificar, traduz-se, assim, como a experimentação da fecundidade da análise. Por fim, no caso das estruturas do meio 4, a descrição estrutural consiste, na maioria das vezes, em deduzir a implicação recíproca dos elementos de um sistema, ou seja, explicar por que, dentro de um espectro de possibilidades lógicas, apenas certas combinações de determinados critérios podem ser empiricamente observadas. Os procedimentos de verificação da análise estrutural aqui, do mesmo modo que no meio do tipo 3 , são difusos. Noutros termos, trata-se de provocar a adesão, mostrando que a teoria explica simplesmente um número tão grande de fatos quanto possível. 
Diante das considerações aqui elaboradas, torna-se ainda mais evidente a necessidade de os pesquisadores em marketing reconhecerem precisamente o contexto de significação da noção de estrutura que utilizam, assim como entenderem as características das teorias que fundamentam (bem como são originadas a partir de) suas análises e as peculiaridades dos objetos que investigam. Assim, por exemplo, deve-se ter em mente que as estruturas subjacentes aos estudos que utilizam as equações estruturais, em sua maioria, estão associadas ao tipo 1 ou 2. Por outro lado, também se deve reconhecer que grande quantidade de objetos estudados na área de marketing, como, por exemplo, as percepções dos sujeitos sobre produtos, processos, marcas, relações ou pessoas, são, em essência, indefinidos, por quanto não se podem circunscrever plenamente. Além disso, verifica-se que boa parte das pesquisas sobre o comportamento do consumidor, por exemplo, adotam axiomáticas fundadas em critérios que não estão completamente livres de ambigüidade.

\section{Princíílos Norteadores das ANÁlises Estruturais e o PAPEl do Pesquisador}

Que fazem, em geral, fazem os estruturalistas em suas análises? Para Bardin (1977, p. 204) eles, acima de tudo, "procuram a ordem imutável sob a desordem aparente, o esqueleto invariável sob a heterogeneidade patente dos fenômenos". Deve-se salientar, no entanto, que não existe uma análise estrutural unívoca. Cada autor, em face das características do seu objeto de estudo e das suas habilidades, desenvolve seus próprios métodos analíticos. Em vista disso, observa-se que tais métodos possuem maiores ou menores semelhanças, num ou noutro ponto. Ainda assim, alguns princípios que se acredita serem subjacentes às mais variadas análises estruturais podem ser destacados ${ }^{(9)}$. $\mathrm{O}$ conhecimento e a reflexão acerca desses princípios ${ }^{(10)}$ são então de suma importância, pois fornecem subsídios à realização de escolhas método-analíticas mais adequadas em face de amplo (talvez até infinito) espectro de possibilidades.

Segundo o princípio da integração em totalidade, os dados devem formar um sistema, cujas propriedades não sejam completamente redutíveis às das partes ${ }^{(11)}$ e cuja alteração em algum elemento possa repercutir sobre todos os outros. Mas não basta considerar o objeto de análise como um todo; é necessário adotar uma atitude explicativa (Boudon, 1974). Não se deve, assim, considerar as estruturas como simples "totalidades emergentes" (como denuncia Piaget, 1979), mas analisá-las em sua constituição interna, numa perspectiva onde, em última instância, é eliminada a oposição entre sistema e elementos, visto que, como o conceito de estrutura opera em todos os níveis, até as unidades mínimas são definidas em termos relacionais (Bonomi, 2001). Questiona-se, portanto, a autosuficiência do dado e, ao invés de se concentrar em coisas e fatos isolados, procura-se descrever e compreender redes de relações (Gil, 1999). No entanto, fatos, coisas ou relações devem ser exatamente observados e descritos, tentando-se evitar que quaisquer preconceitos teóricos alterem indevidamente sua natureza ou importância (Lévi-Strauss, 1996). Este princípio impõe ainda a renúncia (provisória) de uma descrição das propriedades específicas dos objetos estudados, para que se possa fazer emergir as relações (de oposição, de distinção, de transformação etc.), aparentemente dissimuladas, que existem entre eles ou entre seus elementos. Entretanto os objetos não podem deixar de ser analisados em si mesmos (idiograficamente) e em relação com o conjunto (nomoteticamente) (cf. Bicudo, 2000; Lévi-Strauss, 1996). Além disso, para tais análises, deve-se poder contar com certa coerência no tipo de objetos considerados, ou seja, eles devem estar ligados a uma mesma designação (qualquer que seja ela) ou pertencer a um mesmo agrupamento (isto é, a um mesmo gênero ou espécie) (cf. Dor, 1989).

Segundo o princípio da imanência, não se deve recorrer a um elemento extrínseco para explicar um elemento do sistema, pois são as relações do próprio sistema que dão sentido às suas partes. Essa abstração metodológica, como observa Lepargneur (1972), exclui não só o recurso à ideologia, mas toda intromissão de um ponto de vista exterior ao sistema estudado. Assim, Bonomi (2001) entende imanência como a explicitação dos nexos internos do sistema abstraindo-se as ligações que ele mantém com o exterior, quer este se trate, na temporalidade, de elementos pertencentes a um sistema anterior ou sucessivo, ou, na contemporaneidade, de elementos inerentes a sistemas de outra ordem. 
Contudo o autor destaca que tal procedimento não elimina o fator temporal, pois a comparação de elementos pertencentes a sistemas situados diferentemente no tempo não deixaria de assentar na consideração preliminar destes elementos no interior das respectivas estruturas imanentes, à luz das quais eles adquirem seu sentido pleno, tornado-se, assim, disponíveis para a comparação. Com base nisso, pode-se dizer que a pesquisa sobre a gênese de uma estrutura é, de certa forma, guiada pelo conhecimento inicial de seu mecanismo próprio (cf. Godelier, 1968; Lefebvre, 1967).

Segundo o princípio da tipicidade, o que interessa não é a acumulação de dados (aspecto mais relevante em análises indutivas), mas acima de tudo a tipicidade destes. Para se conseguir teorizações coerentes, a partir de uma análise estrutural, o mais necessário não é, pois, a preocupação com a quantidade de dados a serem obtidos, mas a preocupação com a representatividade destes. Noutros termos, o que importa é que os dados sobre os quais se exerce a teoria não sejam meramente acumulados, mas escolhidos (justamente por serem típicos) e que a teoria não seja determinada pelos objetos empíricos aos quais se aplica (Bonomi, 2001). Em vista disso, a teoria não incide sobre datidades fatuais, mas sobre o caráter combinatório e recorrente de suas possibilidades empíricas. A análise estrutural põe em questão, portanto, a prioridade lógica e epistemológica do fatual sobre o possível.

Uma análise estrutural consiste sempre em observar, comparar, classificar, manipular diferenças e relações (Lepargneur, 1972). Assim, segundo o princípio da comparação, deve-se procurar reconhecer entre os conjuntos organizados de dados, que justamente para verificar uma hipótese, são comparados, diferenças que não sejam puras alteridades, mas que sejam significativas e indiquem a relação comum segundo a qual se definem (cf. Pouillon, 1968). Nessa análise, não se trabalha apenas na base da classificação dos signos ou das significações, mas sobre o arranjo dos diferentes itens (material, código ou conteúdo) considerados, tentando estabelecer as constantes significativas nas suas relações (aparentes ou latentes), que organizam estes itens entre si (Bardin, 1977). As explicações emergem, portanto, de uma atenção minuciosa às diferenças e descontinuidades. A questão passa a ser então imaginar as diferenças como combinação de parâmetros, tentar estabelecer os mecanismos que levam às permutas e, no possível, elaborar o quadro teórico das possibilidades de combinações, algumas delas efetivamente observadas (Lepargneur, 1972). Em decorrência da adoção de tais procedimentos, os conjuntos considerados aparecem como variantes uns dos outros.

Em estreita associação com o anterior, o princípio das variações diacrônicas incita à compreensão dos mecanismos que permitem passar de uma forma (variante) de um sistema (conjunto) a outra, dentro do mesmo sistema. Para tanto, deve-se investigar as articulações lógicas de um arranjo, comportamento, texto ou discurso, situando as opções feitas pelos seus autores no campo de suas possibilidades teóricas. A análise revela não apenas as possibilidades, mas também as capacidades de evolução (Godelier, 1968). Destaca-se que o que permanece pode ser tão ou mais importante do que aquilo que desaparece. Mas não se deve esquecer que ele pode permanecer sob diversas formas (os mesmos móveis na loja, mas dispostos de maneira diferente; o mesmo jogo, mas com jogadores diferentes etc.). Por outro lado, conforme Lepargneur (1972), em algumas ocasiões, o que pode esclarecer não é o idêntico que permanece, mas aquilo que mudou. Por que mudou? Como mudou? Até que ponto houve mutação? Segundo que mecanismos? Assim, não é suficiente procurar saber como as coisas são; deve-se buscar compreender também como elas chegaram a ser o que são. Já segundo o princípio da convergência, não se deve buscar o simples reconhecimento de semelhanças entre relações diferentes quanto aos termos (i.e., analogias), mas a convergência das relações semelhantes termo a termo em domínios diferentes. Dessa forma, a procura por convergências assume o caráter de identificação prioritária de homologias (de oposições), muito mais do que o estabelecimento de associações analógicas. Ao comentar tal aspecto, Durand (2002, p. 43) explica que "a analogia é do tipo A é para $\mathrm{B}$ o que $\mathrm{C}$ é para $\mathrm{D}$, enquanto a convergência seria sobretudo A é para $\mathrm{B}$ o que A' é para B'". Em seguida, para esclarecer essa distinção, o referido autor declara que a homologia é equivalência morfológica, mais do que equivalência funcional, e que a convergência pode ser comparada à variação temática.

Segundo o princípio de pertinência, só deve ser considerado o que cabe sob o ponto de vista escolhido para exame do sistema e, desse modo, os elementos não pertinentes devem ser (pelo menos 
momentaneamente) eliminados da análise, embora possam retornar noutros pontos de vista (i.e., análises posteriores). Assim, Lepargneur (1972) lembra que só os elementos portadores de informações são pertinentes em lingüística. Barthes (1983), por sua vez, argumenta que a moda contempla três estruturas (tecnológica, icônica e verbal); mas cada uma deve ser estudada em separado e por meio de análises específicas. Assim, atos, imagens e palavras podem ser estudados, mas não todos de uma só vez, ainda que as estruturas que eles formam se combinem na constituição de um objeto genérico. Lévi-Strauss (1996) também defende a pertinência (considerada agora de modo um pouco diferente), ao declarar que a pesquisa deve restringir-se a uma pequena região de fronteiras nitidamente definidas e as comparações não devem ser estendidas além da área escolhida como objeto de estudo.

Em associação com praticamente todos os outros princípios, encontra-se o princípio da decomposição analítica. Segundo ele, deve-se tomar o objeto de análise, decompô-lo em suas menores partes significantes (fixando as regras de sua associação) e, depois, recompô-lo para fazer aparecer suas funções (cf. Barthes, 1967). Nesse processo, deve-se procurar superar a análise isolada de um código, de uma frase, e até de um discurso, para situá-los nos conjuntos nos quais eles operam. Tendo isso em vista, Bardin (1977, p. 204) afirma que por trás de uma análise estrutural, existe sempre "um gosto pelo jogo do mecânico: desmontar o mecanismo, explicar o funcionamento e ... reencontrar as mesmas engrenagens ou o mesmo motor, qualquer que seja a forma do relógio ou a cor da carroceria". Pode-se dizer então que a adoção desse princípio se configura em uma tentativa de superar (mas não ingenuamente eliminar) o problema da complexidade da realidade. Sob essa perspectiva, como Demo (1995) salienta, na profundeza de sua decomposição analítica, descobre-se que a variação complexa se liga a um tema constante. Assim, de acordo com Boudon (1974), as análises estruturais tornam coerentes os fatos que dão ou podem dar a impressão de arbitrários e de contingentes.

Concomitantemente à discussão dos princípios que norteiam as análises estruturais, é preciso discutir o papel assumido pelo pesquisador na busca das estruturas. Além das corriqueiras preocupações com o rigor método-analítico, existem pelo menos duas outras peculiaridades que são profundamente influenciadas pelo pesquisador. A primeira refere-se ao conjunto de decisões que, direta ou indiretamente, conduzem à formalização utilizada para representar uma estrutura. Como dois ou mais pesquisadores que trabalhem sobre o mesmo conjunto de dados ou objeto podem chegar a formalizações diferentes, ainda que se possa assumir que estas formalizações sejam dotadas de um nível de rigor similar, encontra-se espaço para a realização do seguinte questionamento: seria cada uma dessas formalizações uma estrutura diferente ou seriam apenas modos diferentes de ver uma mesma estrutura? A resposta a esta pergunta remete à consideração da segunda peculiaridade de uma investigação estruturalista, a qual está relacionada com a assunção da natureza ontológica das estruturas e da qual o teórico, por mais que se esforce, não pode deixar de exprimir sua crença.

Enquanto um físico que estuda as propriedades de um material ou um bioquímico que tenta descobrir vacina para um vírus podem dar por certa a existência real de seus objetos de estudo, sem que nisso sejam questionados, a investigação estruturalista sempre está aberta a questionamentos sobre o nível de realidade no qual se deve situar a estrutura. Isto porque, segundo Piaget (1979), não se sabe, a priori, se as estruturas pertencem ao homem, à natureza ou aos dois. Por isso, afirma Viet (1973), diversas respostas podem ser dadas às perguntas: é a estrutura algo real ou simples ficção? É preciso ver nela um esquema abstrato, alguma disposição que permita dar conta dos fatos, ou constitui ela própria uma revelação deles? É ela um poder do objeto ou uma construção do sujeito? Respostas extremas ora conduzem a um realismo ingênuo, assumindo que o objeto tem uma estrutural real à espera de ser, cedo ou tarde, descoberta, ora conduzem a um idealismo platônico, assumindo que a estrutura é apenas criação do intelecto do teórico e não encontra existência válida fora dele. Diante deste quadro, Vexliard (1971, p. 192) entende que o conceito de estrutura pode conter elementos espontâneos e naturais e elementos propostos, criados pelo homem. Assim, "o termo construção poderia ser utilizado para definir esses elementos criados pelo homem, e o de estrutura, para designar a interação dos diferentes elementos". Uma terceira opção, aqui assumida, consiste em fugir dos extremos e considerar a estrutura como construção - já que não existe estrutura sem construção, seja ela abstrata ou genética (cf Boudon, 1974; Piaget, 1979) - do teórico sobre o poder fornecido pelo 
próprio objeto. Noutros termos, assume-se que a estrutura é o resultado da interação do sujeito que apreende e aquilo que é apreendido. Ela representa, pois, um meio de tornar mais inteligível uma realidade e não uma forma de substituir esta última. Acerca disso, considera-se que a busca de maior inteligibilidade não mutila o dinamismo da realidade e está sempre aberta a novas possibilidades (cf. Coelho, 1968). Contudo, como salienta Durand (2002, p. 18), "antes de se falar de "construção de estruturas' é preciso encontrar uma hipótese conceitual, um léxico operatório de estruturas que a prática poderá obrigar depois a modificar".

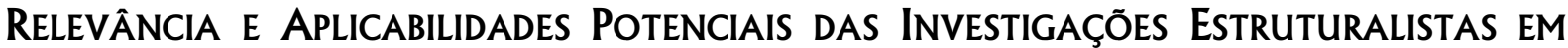 MARKETING}

Em face do exposto nas seções anteriores, pode-se dizer que a relevância das investigações estruturalistas reside, sobretudo, no fato de que os pesquisadores que as utilizam, ao estudarem um fenômeno, não se contentarem com a simples apreensão daquilo que é aparente (i.e., superficialidades que podem ser detectadas por meras observações) ou intencional (declarado), mas buscarem a compreensão dos nexos ocultos, inconscientes ou subjacentes ao que é manifesto pelos elementos que, em dado momento, tomam parte do fenômeno. Com isso, direciona-se a atenção para o entendimento dos diferentes níveis de simbolismos gerados nas interações humanas, mas que também as moldam. Por essa via, tais investigações se tornam relevantes para a área de Marketing, quando se leva em consideração, por exemplo, que a mera observação do comportamento do consumidor não é capaz de dar conta dos reais motivos de suas escolhas, podendo até alguns deles permanecer inconscientes ao sujeito que consome.

As investigações estruturalistas também assumem relevância pelo fato de se concentrarem na compreensão das características das relações que os seus objetos de estudo (ou os elementos que os compõem) mantêm com os demais de sua mesma classe (em dado momento ou espaço) e, com isso, além de ressaltarem a interdependência a que tais objetos (ou elementos) estão sujeitos na determinação de suas próprias identidades, incentivarem a definição de padrões (de variação) por meio dos quais as observações empíricas, em sua multiplicidade, podem ser trazidas a um número restrito de propriedades. Noutros termos, as investigações estruturalistas resultam em teorias que tentam identificar e explicar as naturezas das relações entre os objetos (ex: relações classificatórias, relações de ordem, relações topológicas, etc.) ao mesmo tempo que procuram contornar a dificuldade de integração entre teoria e prática ao fazerem com que as referidas teorias versem não sobre o observado, pura e simplesmente, mas sobre o logicamente [im]possível no fenômeno considerado. Assim, como mencionado anteriormente, as investigações estruturalistas se configuram em alternativas aos estudos positivistas. Pela via em tela, tais investigações assumem relevância para a área de Marketing, quando se leva em consideração, entre outras coisas, o (praticamente irreversível) grau de interconexão das sociedades contemporâneas, a tendência à formação de redes de negócios e diluição das fronteiras organizacionais e a homogeneização de gostos e costumes incentivada pela mídia e levada a cabo por intermédio do trajeto antropológico do imaginário (ver Durand, 2002).

Antes de mencionar as aplicabilidades das investigações estruturalistas, vale destacar que, de acordo com Lévi-Strauss (1996), não existe de antemão um meio de se saber se algo é ou não estruturável. Em reforço a isso, Pouillon (1968) argumenta que a perspectiva estruturalista não está restrita a um domínio que lhe seria próprio (fora do qual não se poderia aplicá-la validamente) e que domínio algum lhe é a priori proibido, embora isto não queira dizer que sua aplicação resolva todos os problemas, apenas que ela pode ser utilizada para abordar a todos, sem, contudo, excluir a possibilidade de aplicação de outros métodos igualmente válidos. Ciente disto, Walle (2002) defende que as investigações estruturalistas, em seus mais variados matizes, possuem um papel legítimo a desempenhar na pesquisa em Marketing, mas que os pesquisadores da área não a utilizam com maior frequiência, devido às suas próprias preferências e agendas de pesquisa e não devido a algum grave problema intrínseco aos métodos desenvolvidos sob a perspectiva estruturalista. 
Pode-se dizer, portanto, que na área de Marketing as investigações estruturalistas possuem enorme potencial de aplicação. Elas podem ser utilizadas, por exemplo, nos estudos sobre posicionamentos de marcas, consideradas como um sistema, onde a propriedade (imagem) de cada elemento (marca) é solidária à propriedade dos demais. Também pode ser utilizada nos estudos sobre redes e canais de distribuição, onde podem ser ressaltadas, entre outras coisas, as configurações que podem ser consideradas impossíveis de ocorrer, bem como o operador (invariante) responsável pela transformação da rede ao longo do tempo. Nesse último caso, vale ressaltar que o fato do objeto de estudo ser considerado um processo não se traduz obrigatoriamente em empecilho para a identificação de suas estruturas (ver Boudon, 1974, p. 107). Além do mais, ainda que os processos tendam a ser associados a uma dimensão diacrônica de análise, enquanto as estruturas a uma dimensão sincrônica, Lepargneur (1972), Piaget (1979) e Bonomi (2001) salientam que a oposição sincronia-diacronia freqüentemente tem sido mal interpretada, à medida que erroneamente lhe é atribuído um valor antinômico. Nesse sentido, Lévi-Strauss (1971a, p. 35) ressalta também que "de fato e de direito existem estruturas diacrônicas e estruturas sincrônicas". Em consonância com essa perspectiva, na área de Marketing, por exemplo, podem ser indicados trabalhos de pelo menos dois autores (Levy, 1999; Walle, 1998) que, embora cada um a seu modo, assumidamente se dispõem a realizar análises estruturais diacrônicas, o primeiro sobre séries de TV que viraram filmes, e o segundo sobre as mudanças que ocorrem nas categorias simbólicas que os consumidores utilizam para classificar marcas e produtos.

As investigações estruturalistas também podem ser utilizadas, por exemplo, no estudo das [inter]relações que podem ser estabelecidas entre as propriedades dos relacionamentos business-tobusiness, consumidor-empresa, consumidor-marca etc. Outra possibilidade de aplicação reside nos estudos sobre os padrões cognitivos de respostas dos consumidores a determinados estímulos (propagandas, por exemplo) ou sobre as ações possíveis (ou socialmente esperadas) em determinados contextos de consumo. Podem ser utilizadas também na interpretação dos sistemas de objetos formados pelos consumidores, bem como na identificação e compreensão do uso dos padrões latentes: mitos e arquétipos, por exemplo nas campanhas promocionais. Estes são apenas alguns dos inúmeros exemplos de aplicações potenciais que podem ser elencados. Cabe ao pesquisador, pois, em face do problema e objeto de pesquisa que possui, optar ou não pela perspectiva estruturalista, tendo consciência dos seus pressupostos e daquilo que ela the pode fornecer.

\section{CONSIDERAÇÕES FINAIS}

Se um dia os limites do estruturalismo puderam ser precisamente traçados, esse momento certamente já se perdeu no tempo. É nítido, entretanto, que o empolgamento por ele outrora gerado nas ciências sociais como um todo arrefeceu (embora ele nunca tenha sido tão grande na área de Marketing quando comparada às demais). Tal fato, por si mesmo, é de certo modo natural e não o invalida, porque, se um dia ele foi realmente uma moda (abraçada por muitos oportunistas apenas pelo seu caráter de novidade), o fim de tal moda não significa que tudo o que foi feito sob sua égide deva ser considerado inócuo; muito pelo contrário, em várias áreas onde foi aplicada, a perspectiva estruturalista levantou questões intrigantes e que até hoje continuam a suscitar debates e investigações.

É verdade que a perspectiva estruturalista não deve ser encarada como panacéia e que muito dos seus resultados são discutíveis (e qual concepção está efetivamente livre disso?); mas decretar (como é o caso, por exemplo, de Giddens, 1999) que ela está morta ou, eufemicamente, declará-la estéril, é mais discutível ainda. Como se pode ter certeza de que o estruturalismo está morto, se ninguém consegue identificar os seus lindes? Alguém consegue precisar se todas as conseqüências foram exauridas em todas as áreas do conhecimento onde ele pode ser considerado aplicável? É óbvio que alguns refinamentos surgiram em contraposição a algumas de suas premissas; mas se ele, apesar disso, ainda tem condições de levantar perguntas interessantes e servir de instrumento para a compreensão da realidade e fomento à ação, como se pode peremptoriamente bani-lo sem cair no preconceito? Afinal 
de contas, não se pode esquecer que, no fundo de todo conhecimento, (mesmo do científico) reside sempre um conjunto de crenças. O estruturalismo, para o qual muitos torcem o nariz ou ficam de cabelo em pé, quando ouvem o seu nome, não é, em si mesmo, melhor ou pior do que outra perspectiva. É, isso sim, uma outra. Cabe aos pesquisadores em Marketing, portanto, nunca perderem isso de vista.

Artigo recebido em 14.02.2008. Aprovado em 13.10.2008.

\title{
NOTAS
}

\begin{abstract}
${ }^{1}$ Ressalta-se que o fato do pensamento estruturalista em geral buscar constantes a-históricas não significa que ele recuse a história (cf. Giddens, 1999), mas sim o historicismo, isto é, a tendência do século XIX a fazer da categoria tempo a chave suprema das explicações dos fenômenos. Sobre isso, Lévi-Strauss, C. (1989). O pensamento selvagem (2a ed., p. 247). Campinas: Papirus, afirma que a história é "indispensável para inventariar a integralidade dos elementos de uma estrutura qualquer, humana ou não humana. Longe, pois, da busca da inteligibilidade chegar à história como seu ponto de chegada, é a história que serve de ponto de partida para toda procura de inteligibilidade ... a história conduz a tudo, mas com a condição de se sair dela”. Por fim, segundo Lepargneur (1972), a crítica que se faz ao 'estruturalismo' de se abstrair do vivido histórico não deveria ser feita no âmbito da história coletiva, mas no plano da vida pessoal.
\end{abstract}

2 Apesar da ênfase colocada pelo referido autor sobre este aspecto, como poderá ser verificado mais adiante, esta característica não é admitida de modo estrito por todas as formas de estruturalismo.

3 Essa distinção é admitida também por Escobar (1967), sendo que para este autor ela seria um 'corte', no plano metodológico, entre as 'ordens vividas' e 'ordens concebidas' conforme advoga Lévi-Strauss.

${ }^{4}$ Contra a procura de uma definição indutiva Boudon (1974, p. 6) comenta também: "Se existem cães empíricos independentemente das definições que se possa dar do conceito de cão, o mesmo não se verifica quanto às 'estruturas', que só existem a partir do momento em que são definidas. Uma análise das definições da noção de estrutura proposta por economistas, sociólogos, psicólogos pode informar sobre estas definições, mas não pode produzir, pela comparação e pela abstração de seus elementos comuns, uma definição da noção de estrutura".

${ }^{5}$ Em relação à distinção entre os dois contextos, Boudon (1974, p. 56) esclarece que "as duas acepções distintas representam muitas vezes dois momentos na análise de um material. Em um primeiro momento, observamos que o material ... apresenta regularidades, que seus elementos são interdependentes, etc. Em um segundo momento, trata-se de fazer a teoria desta interdependência: passamos então do primeiro para o segundo tipo de contexto".

${ }^{6}$ Para Lévi-Strauss (1996, p. 368) também não existe conexão necessária entre a noção de estrutura e a noção de medida. Embora ele reconheça que em diversos domínios, problemas que não comportavam solução métrica puderam, apesar disso, ser submetidos a um tratamento rigoroso, ele afirma que "sem dúvida há, em nossas disciplinas, muitas coisas que se podem medir ... mas não é certo que sejam as mais importantes. ... Percebeu-se que a quantificação dos fenômenos sociais não ia a par, de modo algum, com a descoberta de sua significação".

${ }^{7}$ Como exemplo, Boudon (1974) demonstra que a teoria elaborada por Jakobson para a descrição dos fonemas da língua inglesa permite deduzir a ordem de complexidade destes, mas não a necessidade da coincidência entre esta ordem e a ordem de aparecimento dos fonemas, por exemplo, nas crianças.

${ }^{8}$ Esta noção é tomada por Boudon (1974) como o conjunto de regras ou proposições que definem um cálculo, o qual em geral conduz a decisões não-contraditórias e desconsidera a substância do fenômeno.

${ }^{9}$ Acerca disso, Viet (1973, p. 321) afirma que algumas regras que comandam a análise estrutural em suas diferentes vias podem ser estabelecidas e que elas constituem uma espécie de fundo comum, ao qual vêm, na origem, as correntes do 'estruturalismo' buscar a fonte. Apesar do autor ter falado em 'regras', considera-se mais apropriada a utilização do termo 'princípios', já que nem todas as 'regras' são seguidas de modo estrito por todos e que elas constituem, como ele mesmo ressalta, uma "fonte". Além disso, considera-se que uma regra, em essência, determina algo, enquanto um princípio é algo que, acima de tudo, oferece um norte, uma direção.

${ }^{10}$ Ressalta-se que a seqüência de apresentação dos princípios não está em ordem de importância. Além disso, como alguns deles se encontram em estreita interconexão, reconhece-se a possibilidade de que outros autores encontrem (ou simplesmente advoguem) um número maior ou menor de princípios do que os aqui considerados.

${ }^{11}$ Como um exemplo disso, Piaget (1979, p. 10) menciona que "os números inteiros não existem isoladamente e ... eles não se manifestam senão em função da própria sequiência dos números e esta apresenta propriedades estruturais de 'grupos', 'corpos', 'anéis', etc., bem distintas das que pertencem a cada número que, por seu lado, pode ser par ou impar, primo ou divisível por $\mathrm{n}>1$, etc.”. 


\section{REFERÊNCIAS BIBLIOGRÁFICAS}

Bagozzi, R. P. (1975). Marketing as exchange. Journal of Marketing, 39(4), 314-327.

Barbosa, L. (2003). Marketing etnográfico. GV Executivo, 2(2), 38-43.

Barbut, M. (1968). Sobre o sentido da palavra "estrutura" em matemática. In J. Pouillon, J. Barbut, M. Greimas, A. Godelier, M. Bourdieu, P. Macherey, \& J. Ehrmann. Problemas do estruturalismo (pp. 27-51). Rio de Janeiro: Zahar.

Bardin, L. (1977). Análise de conteúdo. Lisboa: Edições 70.

Barthes, R. (1967). A atividade estruturalista. In C. H. Escobar (Org.). O método estruturalista (pp. 57-63). Rio de Janeiro: Zahar.

Barthes, R. (1983). The fashion system. New York: Hill and Wang.

Bastide, R. (1971). Introdução ao estudo do termo "estrutura". In R. Bastide (Coord.). Usos e sentidos do termo estrutura (pp. 1-12). São Paulo: Editora da Universidade de São Paulo.

Benveniste, E. (1971). "Estrutura" em lingüística. In R. Bastide (Coord.). Usos e sentidos do termo estrutura (pp. 23-31). São Paulo: Editora da Universidade de São Paulo.

Bicudo, M. A. (2000). Fenomenologia: confrontos e avanços. São Paulo: Cortez.

Boas, L., Sette, R., \& Abreu, N. (2004, setembro). Teoria e pesquisa em marketing: a contribuição da antropologia para o estudo do comportamento do consumidor. Anais do Encontro Nacional da Associação Nacional de Pós-Graduação e Pesquisa em Administração, Curitiba, PR, Brasil, 28.

Bonomi, A. (2001). Fenomenologia e estruturalismo (2a ed.). São Paulo: Perspectiva.

Boudon, R. (1974). Para que serve a noção de estrutura? - Ensaio sobre a significação da noção de estrutura nas ciências humanas. Rio de Janeiro: Eldorado.

Carbonnier, J. (1971). As estruturas em direito privado. In R. Bastide (Coord.). Usos e sentidos do termo estrutura (pp. 71-74). São Paulo: Editora da Universidade de São Paulo.

Carvalho, J. L., \& Vergara, S. C. A. (2002). Fenomenologia e a pesquisa dos espaços de serviços. Revista de Administração de Empresas, 42(3), 78-91.

Cerchiaro, I. B., Sauerbronn, J. F., \& Ayrosa, E. A. (2004, novembro). Uma visão alternativa da pesquisa em marketing: como a fenomenologia pode contribuir para gerar conhecimento de marketing. Anais do Encontro de Marketing da Associação Nacional de Pós-Graduação e Pesquisa em Administração, Porto Alegre, RS, Brasil, 1.

Châtelet, F. (1968). Como vai o estruturalismo? In E. P. Coelho (Org.). Estruturalismo: antologia de textos teóricos (pp. 37-43). São Paulo: Martins Fontes.

Coelho, E. P. (1968). Introdução a um pensamento cruel: estruturas, estruturalidade e estruturalismos. In E. P. Coelho (Org.). Estruturalismo: antologia de textos teóricos. São Paulo: Martins Fontes.

Demo, P. (1995). Metodologia científica em ciências sociais (3a ed.). São Paulo: Atlas.

Dichter, E. (1964). Handbook of consumer motivations: philosophy of the worlds of objects. New York: McGraw-Hill. 
Dor, J. (1989). Introdução à leitura de Lacan. Porto Alegre: Artes Médicas.

Douglas, M., \& Isherwood, B. (2004). O mundo dos bens. Rio de Janeiro: UFRJ.

Durand, G. (2002). As estruturas antropológicas do imaginário (3a ed.). São Paulo: Martins Fontes.

Escobar, C. H. (1967). Introdução. In C. Lévi-Strauss (Org.). O método estruturalista (pp. 7-13). (Coleção Textos Básicos de Ciências Sociais). (C. H. Escobar, Trad.). Rio de Janeiro: Zahar. (Obra original publicada em 1951).

Giddens, A. (1999). Estruturalismo, pós-estruturalismo e a produção da cultura. In A. Giddens \& J. Turner (Orgs.). Teoria social hoje (pp. 281-319). São Paulo: UNESP.

Gil, A. C. (1999). Métodos e técnicas de pesquisa social (5a ed.). São Paulo: Atlas.

Godelier, M. (1968). Sistema, estrutura e contradição em “o capital”. In J. Pouillon, M. Barbut, A. Greimas, M. Godelier, P. Bourdieu, P. Macherey, \& J. Ehrmann. Problemas do estruturalismo (pp. 67-103). Rio de Janeiro: Zahar.

Gurvitch, G. (1971). As “estruturas” em sociologia. In R. Bastide (Coord.). Usos e sentidos do termo estrutura (pp. 109-124). São Paulo: Editora da Universidade de São Paulo.

Holbrook, M. B., \& Grayson, M. W. (1986). The semiology of cinematic consumption: symbolic consumer behavior in 'out of Africa'. Journal of Consumer Research, 13(3), 374-381.

Jaime, P., Jr. (2001). Etnomarketing: antropologia, cultura e consumo. Revista de Administração de Empresas, 41(4), 68-77.

Kurzweil, E. (1980). The age of structuralism: Lévi-Strauss to Foucault. New York: Cambridge University Press.

Lagache, D. (1971). Estrutura em psicologia. In R. Bastide (Coord.). Usos e sentidos do termo estrutura (pp. 81-82). São Paulo: Editora da Universidade de São Paulo.

Lefebvre, H. (1967). Reflexões sobre o estruturalismo e a história. In C. H. Escobar (Org.). O método estruturalista (pp. 80-103). Rio de Janeiro: Zahar.

Leitão, D., Lima, D., \& Machado, R. (2006). Antropologia e consumo. São Paulo: AGE.

Lepargneur, H. (1972). Introdução aos estruturalismos. São Paulo: Herder.

Lévi-Strauss, C. (1971a). Os limites do conceito de estrutura em etnologia. In R. Bastide (Coord.). Usos e sentidos do termo estrutura (pp. 33-39). São Paulo: Editora da Universidade de São Paulo.

Lévi-Strauss, C. (1971b). Relatório do colóquio sobre o termo "estrutura". In R. Bastide (Coord.). Usos e sentidos do termo estrutura (pp. 159-194). São Paulo: Editora da Universidade de São Paulo.

Lévi-Strauss, C. (1996). Antropologia estrutural (5a ed.). Rio de Janeiro: Tempo Brasileiro.

Levy, S. (1959). Symbols for sale. Harvard Business Review, 37, 117-124.

Levy, S. (1981). Interpreting consumer mythology: a structural approach to consumer behavior. Journal of Marketing, 45, 49-61.

Levy, S. (1999). Brands, consumers, symbols, and research: Sidney J. Levy on marketing (Chap. 5, pp. 390-405). (Comp. D. W. Rook). London: Sage Publications.

Miller, D. (2000). Teoria das compras. São Paulo: Nobel. 
Motta, F. P., \& Vasconcelos, I. G. (2002). Teoria geral da administração (Cap. 5, pp. 131-168). São Paulo: Thomson.

Neves, L., \& Giglio, E. (2004, setembro). Ethnographic marketing: a critical appraisal of the use of anthropology in marketing research. Anais do Encontro Nacional da Associação Nacional de Pós-Graduação e Pesquisa em Administração, Curitiba, PR, Brasil, 28.

Pagès, R. (1971). O termo "estrutura" e a psicologia social. In R. Bastide (Coord.). Usos e sentidos do termo estrutura (pp. 89-99). São Paulo: Editora da Universidade de São Paulo.

Perroux, F. (1971). Estruturas econômicas. In R. Bastide (Coord.). Usos e sentidos do termo estrutura (pp. 47-57). São Paulo: Editora da Universidade de São Paulo.

Piaget, J. (1979). O estruturalismo. São Paulo: Difel.

Pouillon, J. (1968). Apresentação: uma tentativa de definição. In J. Pouillon, M. Barbut, A. Greimas, M. Godelier, P. Bourdieu, P. Macherey, \& J. Ehrmann. Problemas do estruturalismo (pp. 7-26). Rio de Janeiro: Zahar.

Richardson, R. J. (1999). Pesquisa social: métodos e técnicas (3a ed.). São Paulo: Atlas.

Rocha, E., Barros, C., \& Pereira, C. (2005, setembro). Perspectivas do método etnográfico em marketing: consumo, comunicação e netnografia. Anais do Encontro Nacional da Associação Nacional de Pós-Graduação e Pesquisa em Administração, Brasília, DF, Brasil, 29.

Rocha, E., Blajberg, C., Ouchi, C., Ballvé, F., Soares, J., Bellia, L., \& Leite, M. (1999, setembro). Cultura e consumo: um roteiro de estudos e pesquisas. Anais do Encontro Nacional da Associação Nacional de Pós-Graduação e Pesquisa em Administração, Foz do Iguaçu, PR, Brasil, 23.

Roumeguère, R. (1971). Relatório do colóquio sobre o termo "estrutura". In R. Bastide (Coord.). Usos e sentidos do termo estrutura (pp. 159-194). São Paulo: Editora da Universidade de São Paulo.

Souza, A., Neto, \& Mello, S. C. B. (2006, maio). O relacionamento empresa-consumidor sob o prisma da epistemologia estruturalista. Anais do Encontro de Marketing, Rio de Janeiro, RJ, Brasil, 2.

Stern, B. B. (1995). Consumer myths: frye's taxonomy and the structural analysis of consumer texts. Journal of Consumer Research, 22(2), 165-175.

Thiry-Cherques, H. R. (2006). O primeiro estruturalismo: método de pesquisa para as ciências da gestão. Revista de Administração Contemporânea, 10(2), 137-156.

Vexliard, J. (1971). Relatório do colóquio sobre o termo "estrutura". In R. Bastide (Coord.). Usos e sentidos do termo estrutura (pp. 159-194). São Paulo: Editora da Universidade de São Paulo.

Viet, J. (1973). Métodos estruturalistas nas ciências sociais. Rio de Janeiro: Tempo Brasileiro.

Walle, A. (1998). Evolving structures and consumer response: dynamic transformations of the fugitive and mission impossible. Management Decision, 36(6), 399-406.

Walle, A. (2002). Exotic visions in marketing theory and practice. Westport: Quorum.

Wolff, E. (1971). Uso e significado da palavra "estrutura" em biologia. In R. Bastide (Coord.). Usos e sentidos do termo estrutura (pp. 15-20). São Paulo: Editora da Universidade de São Paulo. 